\title{
Os Desafios da Nova Geração
}

\author{
The challenges of the new generation
}

CELSO FURTADO*****

RESUMO: Conferência na cerimônia de abertura da III Conferência Internacional da RedCelso Furtado, "Desenvolvimento num Contexto de Globalização”.

PALAVRAS CHAVE: Desenvolvimento; crescimento; industrialização.

ABSTRACT: Speech in the Opening Ceremony of the II International Conference Celso Furtado, "Development in a Globalization Context".

KYWORDS: Development; growth; industrialization.

Jel Classification: 010.

Hoje, aqui, reúnem-se economistas de muitos países para trocar experiências e refletir sobre os graves problemas que afligem o mundo em desenvolvimento face ao modelo neoliberal imposto pelo processo de globalização. Num passado não muito remoto, encontros como este mais pareciam conciliábulos a que tinham acesso apenas alguns iniciados. Hoje, graças ao avanço das técnicas da informação, os temas que aqui serão tratados vêm sendo discutidos em redes virtuais, como esta que coorganiza o seminário - junto com o Instituto de Economia da UFRJ e a CEPAL. Seus membros, professores e universitários, dispõem assim dos meios mais adequados para dar continuidade e aprofundar o confronto de idéias, e também para levar ao conhecimento da opinião pública informações valiosas que, com freqüência, os cen- tros de poder mantêm fora de toda visibilidade.

Para alimentar os debates que se seguirão, permitam-me tratar de questões que só à primeira vista parecem especificamente brasileiras: na verdade, são problemas comuns à grande parte dos países em desenvolvimento.

À diferença do que ocorria há quase meio século, quando me coube assu-

\footnotetext{
* Economista.

** Texto apresentado na III Conferência Internacional da RedCelsoFurtado, realizada no Rio de Janeiro, de 4 a 6 de maio de 2004. Este texto não pode ser reproduzido em todo ou em parte em nenhum suporte sem a prévia autorização do autor
} 
mir a pasta do Planejamento e dirigir a elaboração do Plano Trienal, hoje dispomos de um aprofundado conhecimento das estruturas econômicas e sociais do nosso país. Graças a esse conhecimento, fez-se evidente que no Brasil não houve correspondência entre crescimento econômico e desenvolvimento. É mesmo corrente a afirmação de que o país seria um caso conspícuo de mau-desenvolvimento.

Poucas regiões do Terceiro Mundo terão alcançado, nos anos 1950 e 1960, uma taxa de crescimento tão elevada e terão realizado um processo de industrialização tão intenso. A participação do investimento no produto interno brasileiro nesse período atingiu níveis raras vezes igualados, e traduziu um considerável esforço de acumulação, particularmente nos setores de transportes e energia. Porém, nesses anos e nos decênios seguintes, os salários reais da massa da população não refletiram o crescimento econômico. A taxa de subemprego invisível, isto é, de pessoas ganhan- do até um salário mínimo na ocupação principal, manteve-se surpreendentemente alta. E, mais grave, a grande maioria da população rural pouco ou nada se beneficiou desse crescimento. É verdade que, no período referido, a classe média, antes raquítica, passou a ocupar um espaço crescente. No entanto, a emergência de uma classe média afluente, em meio à pobreza, quando não miséria, de praticamente um terço da população, é a evidência maior do malogro da política de desenvolvimento seguida.

Se os vinte anos de regime militar agravaram o mau-desenvolvimento, cabenos indagar por que, agora que a prática da democracia está incorporada à sociedade brasileira, ainda parece tão difícil promover mudanças nesse quadro.

Para se tracejar uma tentativa de resposta, não é demais relembrar certas idéias elementares: o crescimento econômico, tal qual o conhecemos, vem se fundando na preservação dos privilégios das elites que satisfazem seu afã de modernização; já o desenvolvimento se caracteriza pelo seu projeto social subjacente. Dispor de recursos para investir está longe de ser condição suficiente para preparar um melhor futuro para a massa da população. Mas quando o projeto social prioriza a efetiva melhoria das condições de vida dessa população, o crescimento se metamorfoseia em desenvolvimento.

Ora, essa metamorfose não se dá espontaneamente. Ela é fruto da realização de um projeto, expressão de uma vontade política. As estruturas dos países que lideram o processo de desenvolvimento econômico e social não resultaram de uma evolução automática, inercial, mas de opção política orientada para formar uma sociedade apta a assumir um papel dinâmico nesse processo.

No caso brasileiro, há que se enfrentar o problema que condiciona tudo o mais: a recessão. É consensual a afirmação de que a crise que o Brasil enfrenta tem causas múltiplas e complexas, mas talvez nenhuma seja de tanto peso como o descontrole, por parte de sucessivos governos, das alavancas econômico-financeiras. A recessão que se abate atualmente sobre o Brasil tem sua principal causa no corte desmedido nos investimentos públicos, o que gera efeitos particular- 
mente nefastos nas regiões mais dependentes de aplicações do governo federal. Forçar um país que ainda não atendeu às necessidades mínimas de grande parte da população a paralisar os setores mais modernos de sua economia, a congelar investimentos em áreas básicas como saúde e educação, para que se cumpram metas de ajustamento da balança de pagamentos, impostas por beneficiários de altas taxas de juros, é algo que escapa a qualquer racionalidade.

Compreende-se que esses beneficiários defendam seus interesses. O que não se compreende é que nós mesmos não defendamos com idêntico empenho o direito a desenvolver o país. Se continua a prevalecer o ponto de vista dos recessionistas - aqueles que colocam os interesses dos nossos credores acima de outras considerações na formulação da política econômica - temos de nos preparar para um prolongado período de retrocesso econômico, que conduzirá ao desmantelamento de boa parte do que se construiu no passado. A experiência nos ensinou amplamente que, se não se atacam de frente os problemas fundamentais, o esforço de acumulação tende a reproduzir, agravado, o mau-desenvolvimento. Em contrapartida, se conseguirmos satisfazer essa condição básica que é a reconquista do direito de ter uma política de desenvolvimento, terá chegado a hora da verdade para todos nós.

Duas frentes seriam, no meu entender, capazes de suscitar uma autêntica mudança qualitativa no desenvolvimento do país: a reforma agrária e uma industrialização que facilite o acesso às tecnologias de vanguarda.

O desenvolvimento não é apenas um processo de acumulação e de aumento de produtividade macroeconômica, mas principalmente o caminho de acesso a formas sociais mais aptas a estimular a criatividade humana e responder às aspirações da coletividade. É corrente que se diga que a reforma agrária constitui um avanço no plano social, mas envolve um elevado custo econômico. Essa é uma visão equivocada. O verdadeiro objetivo da reforma agrária é liberar os agricultores para que se transformem em atores dinâmicos no plano econômico. As reformas agrárias que desembocaram na coletivização das terras fracassaram do ponto de vista econômico, pois as estruturas agrárias tradicionais engendram a passividade, razão pela qual subutilizam o potencial produtivo do mundo rural, e a grande empresa agrícola moderna pressupõe um alto nível de capitalização e só apresenta óbvias vantagens no plano operacional em setores circunscritos da atividade agrícola.

No caso brasileiro, a estrutura agrária é o principal fator que causa a extremada concentração da renda. Não tanto porque a renda seja mais concentrada no setor agrícola do que no conjunto das atividades produtivas, mas porque, não havendo no campo praticamente nenhuma possibilidade de melhoria das condições de vida, a população rural tende a se deslocar para as zonas urbanas, aí congestionando a oferta de mão-de-obra não especializada.

Uma nova estrutura agrária deverá ter como principal objetivo dar elasticidade à oferta de alimentos de consumo popular. Trata-se de uma pré-condi- 
ção, mas que, por si só, não assegura o desenvolvimento. Este pressupõe a existência do que os economistas costumam chamar de "motor", ou seja, um centro dinâmico capaz de impulsionar o conjunto do sistema. Vale dizer: não existe desenvolvimento sem acumulação e avanço técnico. Seu impulso dinâmico vem da harmonia interna do sistema produtivo em seu conjunto, o que só se torna possível com a industrialização. O problema crucial é definir o tipo de industrialização capaz de gerar o verdadeiro desenvolvimento.

Não pretendo traçar aqui nem sequer um esboço de política industrial para o país. Gostaria apenas de relembrar um ponto. A unificação do mercado nacional, alcançada nos anos 1930, foi exigência de um certo estágio de industrialização. Seus efeitos negativos nas áreas de tecido industrial mais frágil puderam, por algum tempo, ser amortecidos graças aos elevados custos dos transportes inter-regionais. Desde os anos 1950, os transportes passaram a ser amplamente subsidiados, mediante a construção de estradas a fundo perdido e uma política de baixos preços de combustíveis. Hoje, estamos em outro estágio, e o país deveria se voltar para a industrialização que lhe dê acesso às tecnologias de ponta. Mas a questão de fundo não deve ser esquecida: qualquer política de industrialização no Brasil tem de levar em conta a dimensão continental e as peculiaridades regionais do país.

Não é por arrogância que me atrevo a falar a meus colegas economistas em tom conselheiral. A idade não nos outorga direitos mas a experiência nos arma para enfrentar muitos dissabores. Sabemos que uma luta dessa magnitude só terá êxito com a participação entusiástica de toda uma geração. A nós, cientistas sociais, caberá a responsabilidade maior de velar para que não se repitam os erros do passado, ou melhor, para que não voltem a ser adotadas falsas políticas de desenvolvimento cujos benefícios se concentram nas mãos de poucos. 